\title{
IMPACT ASSESSMENT OF LAND USE / LAND Cover Change on Soil Erosion and Rural LIVELIHOOD IN ANDIT TID WATERSHED, NORTH SHEWA, ETHIOPIA
}

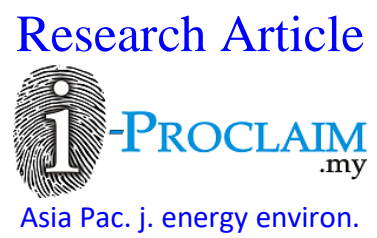

\section{Abrham Tezera Gessesse $^{1 *}$, Tilashwork Chanie ${ }^{2}$, Tesfaye Feyisa ${ }^{3}$, Abdlesemed Jemal ${ }^{4}$}

\author{
${ }^{1,2}$ Soil and Water Conservation Team, Debre Birhan Agricultural Research Center, P.O.Box: 112, Debre Birhan, ETHIOPIA \\ ${ }^{3}$ Soil and Water Conservation Research Directorate, Amhara Region Agricultural Research Institute, Bahir Dar, ETHIOPIA \\ ${ }^{4}$ GIS Expert, Ethiopia Map Agency, Remote Sensing Team Leader, Addis Ababa, ETHIOPIA \\ *Email for Correspondence: abrhamtezera@gmail.com
}

Abstract

Land use, which is use of land by human for different purposes, is influenced by two broad sets of forces human needs (socio-economic) and environmental features and processes (biophysical). The study was carried out at Andit Tid watershed one of SCRP research unit founded in 1982, located on $39043^{\prime} \mathrm{E} 9048^{\prime} \mathrm{N}$. This research has aimed to assess the trend and main driving force of land use and land cover change (LULCC) within the catchment / watershed during the last two decades and its impact on soil erosion. Structural questioner was used to collect social data from $8 \%$ of the total household. Landsat 5 and Landsat 8 Enhanced Thematic Mapper (ETM) and supervised image classification used to identify land use/ land cover change of the study area for 1994 and 2014 years, respectively. TESTMAIN and SPSS version 16 Statistical software's were used for Soil loss calculation and social data analysis, respectively. The result indicates that, there is expansion of cultivated land by $11.33 \%$ (44.55ha) while reduction in natural shrub lands by $7.3 \%$ (35.73ha). The main driving forces of land use land cover change are high number of family member, small land holding size and minimum asset own per household, lower educational level of the household, the household mainly occupied on agriculture and there is lack of animal feed. This change forced farmers to collect cereal crops based on suitability area, sale livestock, use organic and inorganic fertilizer and use improved variety due to low crop productivity. The LULC change has an impact on decline soil fertility, cause serious soil erosion problem with in farmland/watershed. The result also indicated that soil loss reached 3655 ton per annum from the watershed. Therefore, proper handling and land use system need to be implemented, rainwater harvesting structures and soil and water conservation practice need to be encouraged in order reduce soil loss.

Key words

Land use change, Soil erosion, livelihood, Andit Tid

This article is is licensed under a Creative Commons Attribution-NonCommercial 4.0 International License.

Attribution-NonCommercial (CC BY-NC) license lets others remix, tweak, and build upon work non-commercially, and although the new works must also

acknowledge \& be non-commercial.

\section{INTRODUCTION}

Land is the foundation resource for nearly all human uses. Human use of land resources varies from place to place depending on the production objectives and the biophysical capability or suitability of the land itself. Land use, which is use of land by human for different purposes, is influenced by two broad sets of forces human needs (socioeconomic) and environmental features and processes (biophysical) (Turner et al. 1995). Land cover changes influence the biogeochemistry, hydrology, and climate of the earth. Studies that assessed land cover changes at the global scale mostly focused on: deforestation, cropland expansion, dry land degradation, urbanization, pasture expansion, and agricultural intensification (Hartemink et al., 2008). Land use/land cover change is a key driver of global change (Vitousek, 1992) and has significant implications for many international policy issues (Nunes and Auge, 1999). In particular, land use/land cover (LULC) changes in tropical regions are of major concern due to the widespread and rapid changes in the distribution and characteristics of tropical forests (Myers 1993 and Houghton 1994). However, changes in land cover and in the way people use the land have become recognized over the last 15 years as significant global environmental changes in their own right (Turner, 2002). 
The traditional management of land-based resources, coupled with a growing interest and reliance on various products and services from those resources poses a challenge for managing the natural resources. Changes in land use and land cover conditions and agricultural water management practices in irrigation could be responsible for the problems associated with hydrological resources of the Lake Tana Basin (Yitaferu, 2007). Inappropriate allocation and utilization, lack of capacity to develop and use poorly accessible water resources, loss of water due to its seasonality and run off are some of the problems associated with the water resources in the basin. Therefore, producing more food under conditions of increasing water scarcity and without creating further environmental degradation is a challenge being faced (CA, 2007).

To understand how LULC change affects and interacts with earth systems, information is needed on what changes occur, where and when they occur, the rates at which they occur, and the social and physical forces that drive those changes (Lambin, 1997). The information needs for such a synthesis are diverse. Remote sensing has an important contribution to make in documenting the actual change in land use/land cover on regional and global scales from the mid-1970s (Lambin et al., 2003). Mengistu and Salami (2007) investigated the changes in LULC over a period of 16 years in southwestern Nigeria using remote sensing and GIS techniques and deriving factors behind the changes and the adverse effects of these changes on the livelihood of the people and the local environment. In Andit Tid watershed it is obvious that there is land use as well as land cover change, large portion of the study area is covered by cultivated land, but in some parts covered by artificial forest (Eucalyptus plantation). Hence understanding impacts of land use land cover change on the livelihood and soil erosion in this study area is needed for optimal management of natural resources in the area. Therefore to explore and understand the impact of land use land cover on soil erosion, it is also important to assess the trend of LULC change within the catchment/watershed, to assess the main driving force of LULC change in the study area and to analyze the relation of LULC change with soil erosion.

\section{Material AND Methodology}

\section{Description of the study area}

The watershed for this research is one of the catchments of the Soil Conservation Research Programme (SCRP) of the Amhara Regional Agricultural Research Institute (ARARI), which is called Andit Tid. The watershed initiated in 1982 by the Institute of Geography of the University of Bern (Switzerland). Hence in the study area there is more collected and available data for the last 25-30 years. Accordingly Andit Tid is situated in the area of northern Shewa $\left(39^{\circ} 43^{\prime} \mathrm{E}\right.$ and $\left.9^{\circ} 48^{\prime} \mathrm{N}\right)$ and covers a total area of $481 \mathrm{ha}$, and the altitude of the catchment ranges from 3040 to 3548 meter above sea level (Engda et al. 2012).

\section{Social Survey Sampling Procedure and Data Collection}

To collect the required social data for the study individual interview and focus group discussion was conducted. Accordingly 25 households (8\%) of the total households (161) were randomly select and interviewed with structured questioner. Focus group discussions was also made with the development agents (DAs), the watershed community members and PA leaders to supplement and cross check the data obtained through the household individual survey.

\section{Soil erosion}

Annual soil erosion data was obtained and determined from river discharge record and climatic data collected by SCRP/WLRC over the last 20 years.

\section{Land Use Land Cover Change Data Collection and Processing}

The land use land cover of the study area was made based on LandSat5 Thematic Mapper (TM) and LandSat8 Enhanced Thematic Mapper (ETM) for 1994 and 2014 years, respectively and supervised image classification used. Then the images geometrically corrected to Universal Transverse Mercator (UTM) coordinate system. Resolution $30 \mathrm{~m}$ by $30 \mathrm{~m}$, path number 168 Number of rows 53 and 6 Bands were used.

Data on the type and characteristics of the past and present land use and land cover change were generated from Landsat satellite imagery of 1994 TM (Thematic Mapper), and 2014 Landsat 8 at 30m spatial resolution for both satellite imageries. On top of that, Topo sheets with a scale of 1:50,000 were scanned and used for geo-referencing the Landsat satellite images. Field observations, interviews, and discussion with the land users were also employed to substantiate the information.

Landsat satellite image contain a detailed record of features on the ground at the time of exposure. In order to obtain the desired information from the series of satellite images, interpretation should proceed by systematic way. The preimage interpretation phase was done based on visual interpretation in relation to the study area. Once the overall aim was defined, the level of details and the categories of land use/cover that needed to be distinguished were 
determined. Interpretation and analysis of satellite images has been made in the remote sensing departments of Ethiopian Mapping Agency (EMA) following the procedures given below:

a) The 1994 satellite image(TM) for the study is acquired and band combination of 4,3,2 infrared, red and green wavelength of the electromagnetic spectrum were selected respectively to acquire the best information on land use land cover features from the image. The study area was clipped out from the combined image using the subset tool of ERDAS 2010 software.

b) The satellite images of each year were geo-referenced into a map coordinate system using the Universal Transverse Mercator (UTM) projection using clearly observed and selected control points on 1:50,000 topographic map using ERDAS 2010 with 0.5 Root Mean Square (RMS) error.

c) In order to extract the study area and fix the area of interest (AOI) the satellite images of each year were transferred from Tiff (tagged image file format) into image format using ERDAS (Environmental research design and analysis system) 2010 software. Since the satellite images were changed into image and each image had to be rectified and referenced into UTM (universal transverse Mercator) coordinates because the coordinates were discarded when the image was imported from Tiff format to image format.

d) The identification and classification of land use/land cover types from the satellite images require intensive use of spectral band combination for visual verification, because the satellite images were black and white in the first place and they were combined to get a meaning full color of the land use land cover features. The visual interpretation of various features on the characteristics of satellite images, i.e. tone, texture, shape, pattern, shadow, association and aspect as well as location of the features was done with the support of field verification of each land use/cover features.

However, the satellite image was interpreted with the aid of field collected ground truth using global positioning system (GPS) and ERDAS 2010 software. Moreover, supervised classification, using the maximum likelihood classifier was used to classify the satellite images and generate distinct land use/cover types. The maximum likelihood algorism is the most powerful classification methods when accurate training data is provided and one of the most widely used algorithm. Training data or spectral signatures for the supervised classification were established from the previous knowledge of the area, and with the help of other supporting data sources such as satellite images, topographic maps and interviews with elderly people of the area.

The classification result was passed to its accuracy and the accuracy assessment task was done using ERDAS 2010 by selecting 20 random points from both classified images and the ground truth data which were collected using handheld GPS and the accuracy of the classification found to be $80 \%$ with the kappa statistics of 0.75 which is acceptable for classification using Landsat imageries.

Table 1: Producer, user and overall land accuracy of the classification (1994-2014)

\begin{tabular}{|l|c|c|c|c|c|}
\hline LULC classes & Reference Total & Classified Total & Number Correct & Producers Accuracy & Users Accuracy \\
\hline Woodland & 5 & 7 & 5 & $100.00 \%$ & $71.43 \%$ \\
\hline Forest land & 3 & 3 & 2 & $66.67 \%$ & $66.67 \%$ \\
\hline Crop land & 4 & 2 & 2 & $50.00 \%$ & $100.00 \%$ \\
\hline Shrub land & 3 & 2 & 2 & $66.67 \%$ & $100.00 \%$ \\
\hline Grass land & 5 & 6 & 5 & $100.00 \%$ & $83.33 \%$ \\
\hline Total & 20 & 20 & 16 & & \\
\hline
\end{tabular}

Overall Classification Accuracy $=80.00 \%$

Overall Kappa Statistics $=0.7531$

In order to prepare an output map, theses classified coverage features were transferred into Thematic Map using Arc GIS 10.

The land use land cover change statistics of the area between 20 years is calculated using the following formula and the output is presented in table.

The rate of change $=\mathrm{Y} 2-\mathrm{Y} 1 / \mathrm{N}$

Where $\mathrm{Y} 1=$ the Area in hectare of the land use feature in the oldest year (1994)

$\mathrm{Y} 2=$ the area in hectare of the land use feature in the recent year (2014)

$\mathrm{N}=$ the time interval in years between the two imageries (1994-2014)

\section{DATA ANALYSIS}

In addition to image data analysis, the socio-economic data as well soil erosion data were analyzed using SPSS version 19 and TESTMAIN software, respectively. 


\section{Result AND Discussion}

\section{Land use and cover change at Andit Tid Watershed}

As shown in figure 1, there is spatial image difference and land use system at Andit Tid watershed between 1994 and 2014.

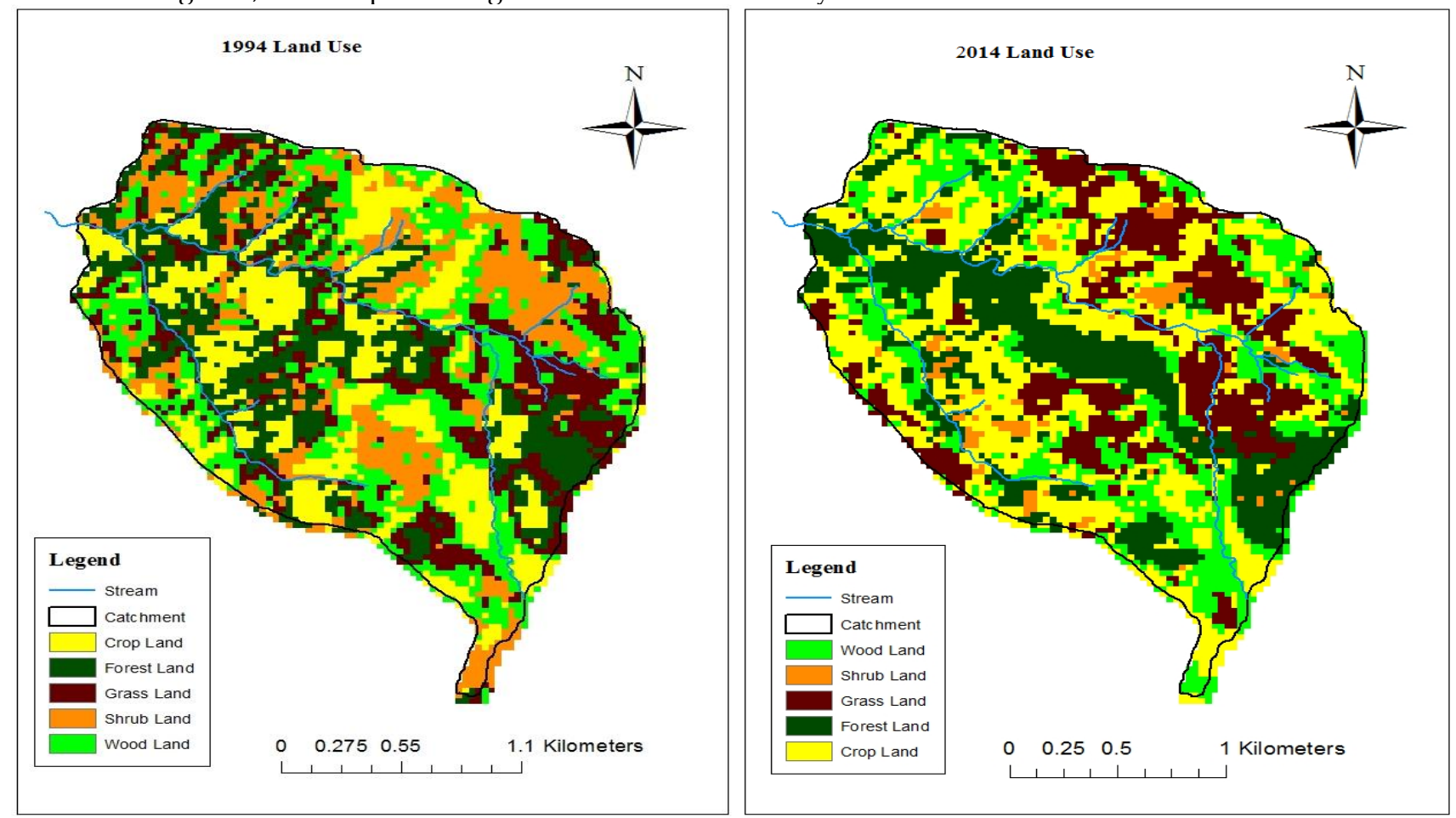

Figure 1: 1994 and 2014 Land Use system Andit Tid watershed

Table 2: Land use and land cover change at Andit Tid watershed between 1994 and 2014.

\begin{tabular}{|l|c|c|c|c|c|c|}
\hline \multirow{2}{*}{$\begin{array}{l}\text { Land } \\
\text { Use Type }\end{array}$} & \multicolumn{2}{|c|}{$\mathbf{1 9 9 4}$} & \multicolumn{2}{c|}{$\mathbf{2 0 1 4}$} & \multicolumn{2}{c|}{ LULC } \\
\cline { 2 - 7 } & Area (ha) & $\mathbf{\%}$ & Area (ha) & \% & +/- (ha) & (+/- \%) \\
\hline Cultivated Land & 113.85 & 23.27 & 169.29 & 34.61 & +55.44 & +11.33 \\
\hline Forest land & 96.57 & 19.74 & 86.4 & 17.66 & -10.17 & -2.04 \\
\hline Shrub Land & 88.65 & 18.12 & 52.92 & 10.82 & -35.73 & -7.30 \\
\hline Grass Land & 88.92 & 18.18 & 83.25 & 17.02 & -5.67 & -1.16 \\
\hline Wood land & 101.16 & 20.68 & 97.29 & 19.89 & -3.87 & -0.79 \\
\hline Total & 489.15 & 100.00 & 489.15 & 100 & & \\
\hline
\end{tabular}

As shown in table 2 and figure 1, cultivated land was increased from 113.85ha to 169.29ha during the last 20 years. This encountered about 11.33 percent or 55.44 ha increment than other land use system. Shrub land reduced highly and by 7.3 percent or by 35.73ha. On the other hand, forest land, grass land, and wood lands were also reduced by 10.17ha, 5.67ha, and 3.87ha, respectively between 1994 and 2014 land use system of the study area. In Ethiopia agricultural land expansion was taking the leading on land use land cover change. Studies conducted at Humera, Metama and Gambela parts of Ethiopian drylands are agricultural lands were increased by $20.77 \%, 44.64 \%$ and $244 \%$ and woodlands were decreased by 41.69\%, 43.71\% and 57.82\%, respectively (Woreku Zewdie and Mengistie Kindu, 2011).

\section{The main driving force (causes) to LULCC}

Table 3: Household number, Asset owned and land holding size of the study area

\begin{tabular}{|c|c|c|c|c|c|c|}
\hline \multicolumn{7}{|c|}{ Descriptive Statistics } \\
\hline \multirow[t]{2}{*}{ Causes of land cover change } & $\mathrm{N}$ & Minimum & Maximum & \multicolumn{2}{|c|}{ Mean } & Std. Dev. \\
\hline & Statistic & Statistic & Statistic & Statistic & Std. Error & Statistic \\
\hline HH Number & 25 & 2 & 10 & 5.48 & .366 & 1.83 \\
\hline Asset Owned (ETB) & 25 & $\$ 464$ & $\$ 124,585$ & $\$ 50,638$ & $\$ 5,600$ & $\$ 28,002$ \\
\hline Land Holding (Ha) & 25 & 0.5 & 3.0 & 1.72 & 0.13 & 0.66 \\
\hline
\end{tabular}

From table 3 the result shows that the mean numbers of the family of the study area is 5.48 per household. This indicated that the asset distribution and land holding between family members is 9,240 ETB and 0.314 ha, respectively. This is an implication for the main cause of land use land cover change in the study area. According to a survey made in Amhara 
region, $12.8 \%$ of the rural households have no access to land (Adenew and Abdi, 2005). Hence, it will be imperative to look for other options of addressing the growing shortage of land and landlessness. A survey conducted in Ethiopia by Mulugeta and Kassa, (2011) stated that among the main factors affecting forest cover are high population growth, lack of awareness, low income, and poverty, educational background, highly dependent on agriculture ( crop production).

Table 4: Education, occupation and feeding system of the study area

\begin{tabular}{|l|l|c|c|c|}
\hline Labels & Description & Frequency & Percent & MSE \\
\hline \multirow{4}{*}{ Education } & Illiterate & 5 & 20.0 & \\
\cline { 2 - 4 } & Read and write & 14 & 56.0 & \\
\cline { 2 - 4 } & Primary (1-4 grade) & 2 & 8.0 & \multirow{3}{*}{0.210} \\
\cline { 2 - 4 } & Junior (5-8 grade) & 3 & 12.0 & \\
\cline { 2 - 4 } & High school (9-10 grade) & 1 & 4.0 & \\
\hline \multirow{3}{*}{ Occupation } & Agriculture & 24 & 96.0 & \multirow{2}{*}{0.120} \\
\cline { 2 - 4 } & Trade & 1 & 4.0 & \\
\hline
\end{tabular}

On the other hand most (76 percent of the respondent) household leaders of the watershed are illiterate and read and write only. Knowledge and awareness gap between community lead to improper land use system. Most of the community members (96 percent) in the study area are occupied on agriculture productivity. This causes the diversification of agricultural lands than improving productivity per unit area.

\section{Impact of LULC Change on Household livelihood and Soil erosion}

Table 5: crop selection criteria

\begin{tabular}{|l|c|c|c|c|c|c|c|c|c|c|}
\hline \multirow{2}{*}{$\begin{array}{c}\text { Crop } \\
\text { production }\end{array}$} & \multicolumn{2}{c}{$\begin{array}{c}\text { Suitability } \\
\text { to the area }\end{array}$} & \multicolumn{2}{c|}{$\begin{array}{c}\text { Household } \\
\text { consumption }\end{array}$} & \multicolumn{2}{c|}{$\begin{array}{c}\text { High demand } \\
\text { (sale) }\end{array}$} & \multicolumn{2}{c|}{$\begin{array}{c}\text { High } \\
\text { Yield }\end{array}$} & \multicolumn{2}{c|}{$\begin{array}{c}\text { Not yet } \\
\text { practiced }\end{array}$} \\
\cline { 2 - 13 } & Frequency & $\%$ & Frequency & $\%$ & Frequency & $\%$ & Frequency & $\%$ & Frequency & $\%$ \\
\hline Cereals & 14 & 56 & 10 & 40 & 1 & 4 & - & - & - & - \\
\hline Vegetable & 4 & 16 & 5 & 20 & 11 & 44 & 1 & 4 & 4 & 16 \\
\hline Fruit trees & - & - & - & - & 3 & 12 & - & - & 22 & 88 \\
\hline Pulses & 1 & 4 & 18 & 72 & 3 & 12 & 1 & 4 & 2 & 8 \\
\hline Oil crops & 2 & 8 & 4 & 16 & 8 & 32 & - & - & 11 & 44 \\
\hline
\end{tabular}

As shown in table 5, 56 percent of the respondent farmers were forced to adjust their crop selection criteria base on their land suitability for specific cereals (barley and wheat) for long period of time. From farmers' point of view, they are not preferable to grow crops for household consumption, high market demand, and high yield crops.

Table 6: Impact of land uses land cover change on crop productivity and Input use at household

\begin{tabular}{|c|c|c|c|c|}
\hline Labels & Description & Frequency & Percent & MSE \\
\hline \multirow{3}{*}{ Fertility status } & Fertile & 4 & 16.0 & \multirow{3}{*}{0.133} \\
\hline & Moderate & 14 & 56.0 & \\
\hline & Infertile & 7 & 28.0 & \\
\hline \multirow{2}{*}{ Crop failure encounter } & Yes & 21 & 84.0 & \multirow{2}{*}{0.075} \\
\hline & No & 4 & 16.0 & \\
\hline \multirow{2}{*}{ Organic Fertilizer use } & Yes & 22 & 88.0 & \multirow{2}{*}{0.066} \\
\hline & No & 3 & 12.0 & \\
\hline \multirow{2}{*}{ Inorganic Fertilizer use } & Yes & 22 & 88.0 & \multirow{2}{*}{0.066} \\
\hline & No & 3 & 12.0 & \\
\hline \multirow{2}{*}{ Improved crop Variety use } & Yes & 22 & 88.0 & \multirow{2}{*}{0.066} \\
\hline & No & 3 & 12.0 & \\
\hline \multirow{6}{*}{ Selling Agricultural Products } & Cereals & 4 & 16.0 & \\
\hline & Vegetable & 3 & 12.0 & \\
\hline & pulses & 3 & 12.0 & \\
\hline & Livestock & 13 & 52.0 & \\
\hline & Wood products & 1 & 4.0 & \\
\hline & None & 1 & 4.0 & \\
\hline \multirow{2}{*}{ Feed shortage ${ }^{* *}$} & Yes & 14 & 58.3 & \multirow{2}{*}{0.103} \\
\hline & No & 10 & 41.7 & \\
\hline
\end{tabular}

** Number of respondent $(\mathrm{N})=24$ having livestock 
As shown in table 6, the farmland soil fertility status of most farmers infertile and moderately fertile. This leads to 84 percent of the respondent crop failure encountered, 88 percent forced to use organic and inorganic fertilizer and improved crop variety to gain affordable yield for their household consumption. 52 percent of the respondents were sale their livestock to compensate low crop production. The other impact of land use and land cover change in the study area there is a lack of animal feed, this leads to the reduction of shrub lands and grass lands.

Table 7: Impact land use land cover change on soil erosion

\begin{tabular}{|c|c|c|c|c|}
\hline Labels & Description & Frequency & Percent & MSE \\
\hline \multirow{2}{*}{ Soil erosion problem } & Yes & 22 & 88.0 & \multirow{2}{*}{0.066} \\
\hline & No & 3 & 12.0 & \\
\hline \multirow{4}{*}{ Seriousness ${ }^{* *}$} & Very sever & 6 & 27.3 & \multirow{4}{*}{0.201} \\
\hline & Sever & 9 & 40.9 & \\
\hline & Moderate & 5 & 22.7 & \\
\hline & Some & 2 & 9.1 & \\
\hline \multirow{4}{*}{ Erosion type $e^{* *}$} & Sheet erosion & 8 & 36.4 & \multirow{4}{*}{0.160} \\
\hline & Rill erosion & 12 & 54.5 & \\
\hline & Splash erosion & 1 & 4.5 & \\
\hline & Gully erosion & 1 & 4.5 & \\
\hline \multirow{4}{*}{ Source of erosion** } & Upper/top part & 11 & 50.0 & \multirow{4}{*}{0.204} \\
\hline & Middle/central & 5 & 22.7 & \\
\hline & Bottom/lower & 5 & 22.7 & \\
\hline & Some parts & 1 & 4.5 & \\
\hline \multirow{4}{*}{ Erosion Pattern ${ }^{* *}$} & Highly increased & 9 & 40.9 & \multirow{4}{*}{0.232} \\
\hline & Moderately increased & 9 & 40.9 & \\
\hline & Moderately stabled & 4 & 18.2 & \\
\hline & Highly increased & - & - & \\
\hline \multirow{3}{*}{ Erosion Impact** } & Yield reduction & 8 & 36.4 & \multirow{3}{*}{0.105} \\
\hline & Removal of top soil & 14 & 63.6 & \\
\hline & Increase Input & - & - & \\
\hline \multirow{2}{*}{ Maintenance of SWC } & Yes & 22 & 88.0 & \multirow{2}{*}{0.066} \\
\hline & $\mathrm{No}$ & 3 & 12.0 & \\
\hline
\end{tabular}

** Number of Respondent $(\mathrm{N})=22$

Land covered by vegetation or herbaceous tree/shrub species reduce the occurrence of erosion because it reduces the kinetic energy of the rain storm and the surface run off. However in the study area there is high erosion problem on farmlands $(88 \%)$. It has a severe problem loss of top soil from their farmland. The erosion type caused by land use land cover change is mostly sheet and rill erosion $36.4 \%$ and $54.5 \%$, respectively. In order to reduce soil erosion problem the government and SCRP projects implement huge soil and water conservation practices.

\section{Impact on annual precipitation and sediment loss of Andit Tid watershed}

According to respondents, following transformation in land use and land cover over the study areas, the climatic condition has changed significantly. They replied that a trend towards a shorter rainy season that starts later and finishes earlier with an intensive pattern as compared to the old times. The automated installed rain-gauge data in study area supported the respondents' idea as shown in figure 2 which ranges from $1278 \mathrm{~mm}$ to $1894 \mathrm{~mm}$ per annum. On the other hand the annual river station discharge rate range from $1.01^{*} 10^{6} \mathrm{~m}^{3}$ to $5.2^{*} 10^{6} \mathrm{~m}^{3}$ and annual sediment loss of the watershed ranges from 436 ton to 3566 ton (figure 3). 


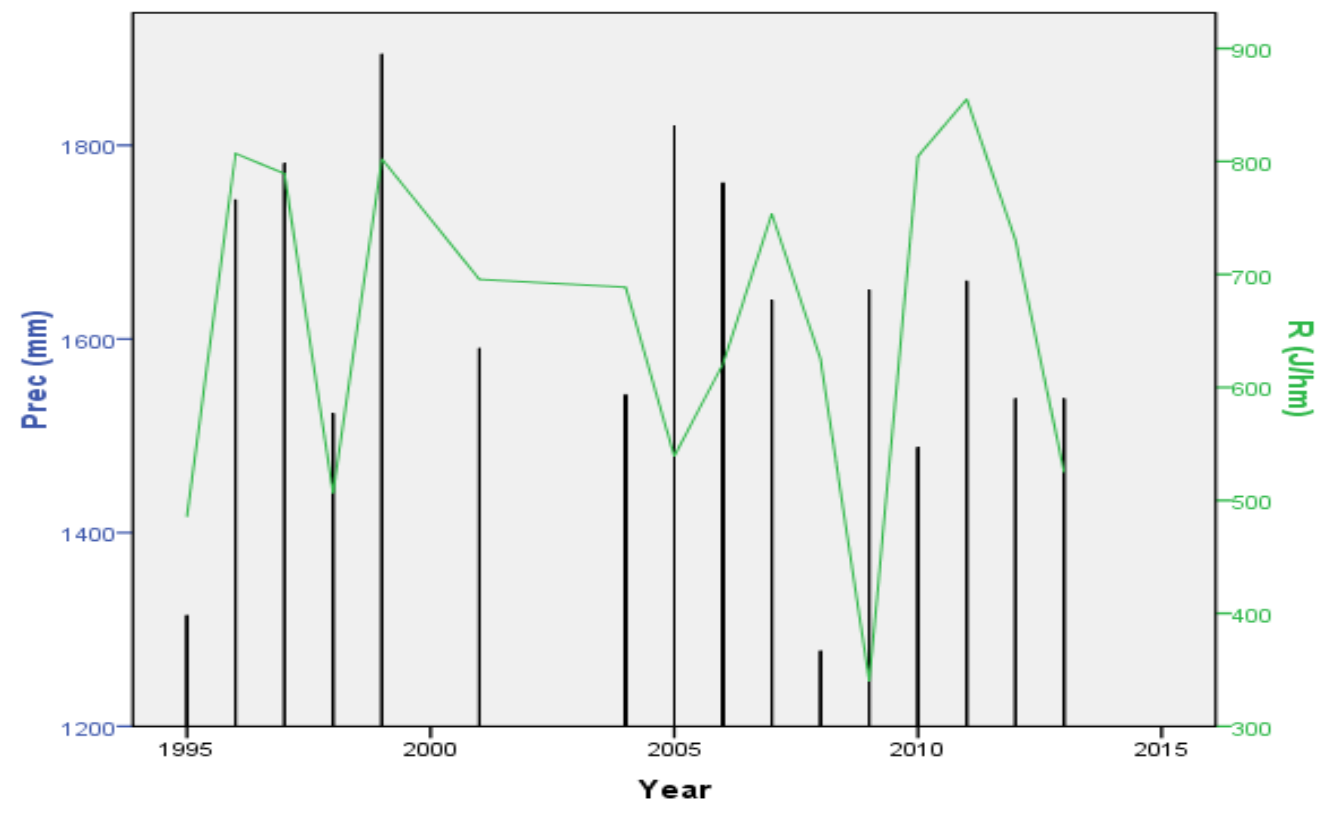

Figure 2: Annual precipitation and rainfall erosivity (R) of the study area 1994-2013.

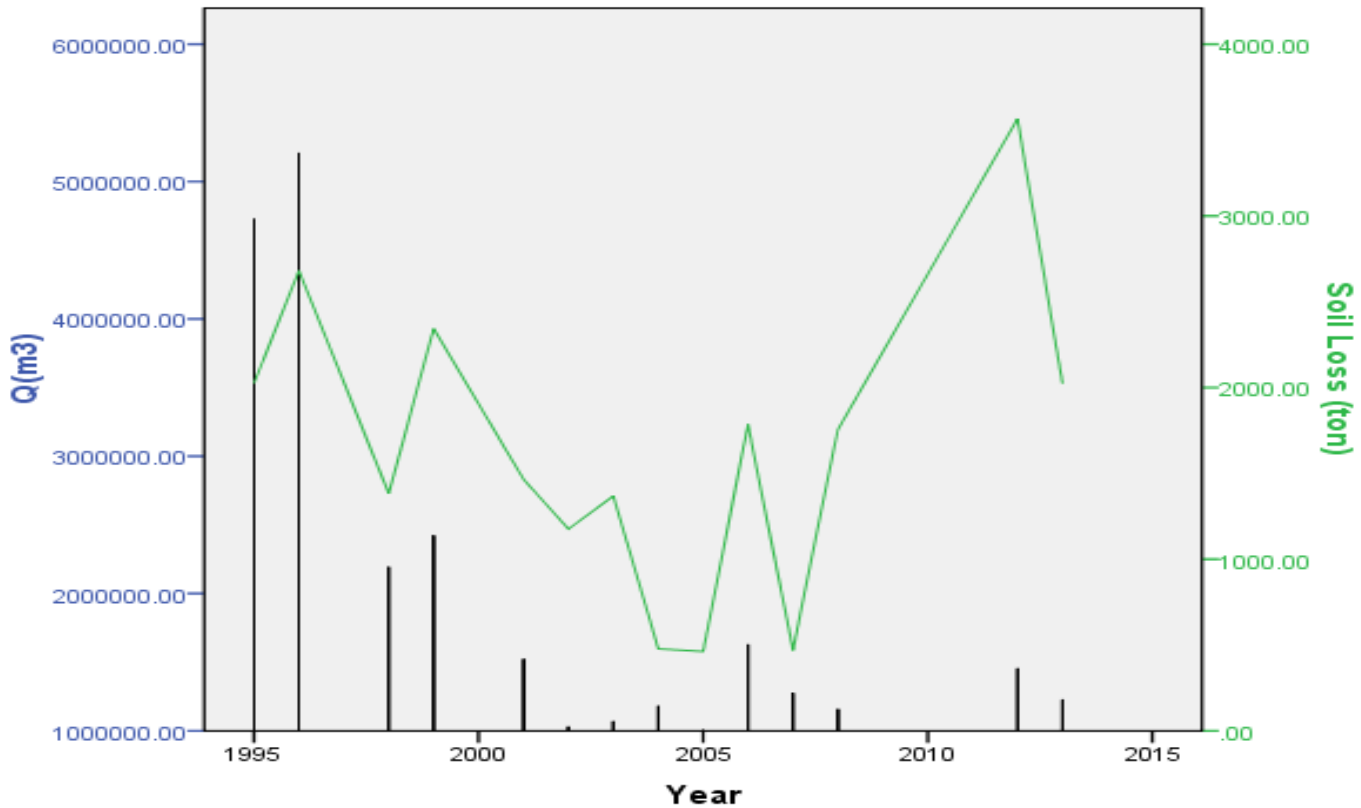

Figure 3: Annual river discharge and soil loss of the study area $1994-2013$.

\section{Conclusions ANd ReCOMmendations}

Land is the foundation of nearly all resource use by human while its utilization varies from place to place depending on biophysical capability or suitability of the land by itself. Inappropriate management of land resources, coupled with a growing interest and reliance on various products and services from those resources poses a challenge for managing the natural resources. Understanding the LULC change with the earth system by different modern applications system was crucial to generate information how land use and land cover change affect the land productivity and livelihood status of the community. In the study area (Andit Tid watershed) it is obvious that there is land use as well as land cover change while scientific evidence on LULC change scanty. A large portion of the study area is covered by cultivated land, but in some areas covered by artificial forest (Eucalyptus plantation).

This study confirms that, the watershed is highly affected by land use land cover change between 1994 and 2014 . During these two decades, agricultural land (cultivated land) was increased by $11.33 \%$ while other land use were decreased. The result demonstrated that the main driving force for land use land cover change are; poor land use 
system, and high number of family member verses low asset owned and small land holding size per household, and the community highly dependent rainfed agriculture (96\%) than other off-farm activities, and lack of awareness, adverse climatic condition (frost) and erratic rainfall.

LULC change that had seen in the watershed indicates that, farmers were forced to use local cereal varieties than improved cereals and other cash crops. Reduce fertility status, high and sever erosion pattern, frequent crop failure, use higher amount inputs, selling of their products (especially their livestock) and feed shortage for their animals' are the main impact caused by LULC change in the watershed while they try to construct and maintain their farmland by soil and water conservation structures.

Land use system, lack of soil and water conservation measure and rainfall pattern lead to crop failure and loss of top soil in the watershed. Therefore, at least at household level rainwater harvesting structures should be constructed to reduce crop failure, to increase irrigation options for vegetables and fruits, and to minimize soil erosion. Awareness creation on land use land cover change, provision of climate smart new improved crop varieties and cash crops must be done by research centers and development organizations. The watershed needs proper land use system by avoiding allocation of new farmland and further study on land use system analysis is required.

\section{ACKNOWLEDGEMENT}

This research is supported by Amhara Region Agricultural Research Institute (ARARI) and Water and Land Resource Center (WLRC).

\section{REFERENCE}

Adenew, B. and Abdi, F., 2005. Land Registration in Amhara Region, Ethiopia Research Report 4. London: International Institute for Environment and Development.

CA (Comprehensive Assessment of Water Management in Agriculture), 2007. Water for Food, water for Life: A Comprehensive Assessment of Water Management in Agriculture. Earthscan, London, UK and International Water Management Institute, Colombo, Sri Lanka.

Engda, T. A., H. K. Bayabil, E. S. Legesse, E. K. Ayana, S. A. Tilahun, A. S. Collick, Z. M. Easton, A. Rimmer, S. B. Awulachew, and T. S. Steenhuis. 2011. Watershed hydrology of the (semi) humid Ethiopian highlands. In Nile River: Hydrology, Climate, and Land Use, 145-162. A. Melesse, ed. New York, N.Y.: Springer Science

Hartemink, A.E., Veldkamp, T., Zhanguo, B., 2008. Land Cover Change and Soil Fertility Decline in Tropical Regions. Turk J Agric For 32 (2008) 195-213.

Houghton RA (1994). The worldwide extent of land-use change. Biological Science 44: 305-313.

Lambin, E. F., 1997a. Modelling and Monitoring Land-Cover Change Processes in Tropical Regions. Progress in Physical Geography. 21, 375-393.

Lambin, E.F., H.J. Geist, and E. Lepers. 2003. Dynamics of land-use and land-cover change in tropical regions. Annual Review of Environment \& Resources. 28: 205-241.

Mengistu, D. A. and Salami A.T., 2007. Application of remote sensing and GIS inland use/land cover mapping and change detection in a part of south western Nigeria. African Journal of Environmental Science and Technology Vol. 1 (5), pp. 099-109

Mulugeta L., \& Kassa, H. (2011). Challenges and forest-based opportunities in the drylands of Ethiopia. In M. Lemenih, \& H. Kassa (Eds.), Opportunities and challenges for sustainable production and marketing of gums and resins in Ethiopia (pp. 1-12). Bogor, Indonesia: CIFOR.

Myers N (1993). Tropical forests: the main deforestation fronts. Environmental Conservation. 20: 9-16.

Nunes C, Auge JI (1999). Land-Use and Land-Cover Implementation Strategy (Stockholm: IGBP).

Turner BL II (2002). Toward integrated land-change science: Advances in 1.5 decades of sustained international research on landuse and land cover change: in Steffen W, Jäger J, Carson.

Turner, B. L., II, Skole, D., Sanderson, S., Fischer, G., Fresco, L., and Leemand, R. (1995). LandUse and Land-Cover Change: Science/Research Plan. IGBP Report No. 35 and HDP Report No. 7. IGBP, ICSU, HDP and ISSC, Stockholm and Geneva

Vitousek, P.M., 1992. Global Environmental Change: An introduction. Ann. Rev. Ecol. Syst. 23: 1-14.

Worku Zewdie and Mengistie Kindu (2011). Land use land cover change analysis in selected drylands of Ethiopia: Implication for sustainable development. Annual proceeding of Research and Development in Dryland forests of Ethiopia. Forum for Environment. 123-135.

Yitaferu, B., 2007, Land Degradation and Options for Sustainable Land Management in the Lake Tana Basin (LTB), Amhara Region, Ethiopia. PhD thesis, Centre for Development and Environment, University of Bern, Switzerland.

$$
-0 \text {-- }
$$

